\title{
A VÁROSKUTATÁSOK TOVÁBBFEJLESZTÉSÉNEK SZEMPONTJAI: AZ EURÓPAI VÁROSTUDOMÁNYOK JÖVÖJE
}

\author{
(The Principles of Development of Urban Studies: \\ the Future of the European Urban Sciences) \\ SZIRMAI VIKTÓRIA
}

Kulcsszavak:

várostudományok módszertani fejlödése európai és magyar városkutatások tematikája városi társadalmi problémák új kutatási irányok

A tanulmány a legújabb szakirodalmak és egy nemzetközi konferencia tapasztalatai alapján bemutatja az európai és a hazai magyar városkutatások fontosabb kutatási témáit, a kutatási témákat meghatározó várostérségi társadalmi folyamatokat, a városkutatások továbbfejleszzésének lehetséges módszertani szempontjait és új irányait.

\section{Bevezetés}

Egy, a várostudományok jövőjével foglalkozó tudományos konferencia nemcsak sokat ígérő címe miatt volt érdekes, hanem azért is, mert újabb bizonyítékát adta annak, hogy a város problematika nemzetközi jelentösége folyamosan növekszik. 2005. május 26. és május 28. között az European Sciences Foundation nemzetközi konferenciát szervezett Helsinkiben ${ }^{1}$. A konferencián a várostudomány legkülönbözőbb tudományági képviselői, fóként akadémiai kutatók, egyetemi tanárok jelentek meg, nagyobb részben városgeográfusok, közgazdászok, városszociológusok, kisebb részben ökológusok, építészek, várostervezök, várospolitikusok is.

A „Forward Look in Urban Science, Final Conference” több korábbi (különböző országokban rendezett) workshop munkáját is összegző zárókonferencia alapvető célja az volt, hogy összegezze a legidőszerübb városi társadalmi, gazdasági, urbanisztikai problémákat, hogy kijelölje a legfontosabb jövőbeni városkutatási irányokat. Az új kutatási irányokra az ESF további támogatási irányainak a definiálásához, továbbá az Európai Unió következő, 7. számú nagy kutatási programja témáinak a megfogalmazásához is szükség volt. A zárókonferencia célja volt az is, hogy vitát nyisson az európai várostudományok lehetséges jövőjéről, az ezzel kapcsolatos meghatározó folyamatokról. Az európai helyzet minél jobb megértését szolgálta, hogy a világ más régióiból is meghívtak kutatókat, s így nemcsak az európai, hanem az amerikai, kínai, afrikai városokról is esett szó.

$\mathrm{Az}$ alábbi tanulmányban nem a konferencián történtek összegzésére, hanem arra vállalkozom, hogy részben a konferencián elhangzottak, részben a legújabb szakirodalmak alapján elhelyezzem a magyar városkutatási témákat, kutatási eredményeket az európai városkutatási irányok mai főbb trendjeiben. A tanulmány kísérletet 
Szirmai Viktória : A városkutatások továbbfejlesztésének szempontjai:

Az európai várostudományok jövője. Tér és Társadalom 19. évf. 2005/3-4. 43-59. p.

tesz arra is, hogy bemutassa azokat az új kutatásmódszertani szempontokat, amelyeket a friss szakirodalmak különösen fontosnak tartanak, és amelyeket a konferencián elhangzott elöadások is megfogalmaztak. A tanulmányhoz felhasználtam azt az összegzést, amelyet a szervezők kérésére készítettem a magyarországi városkutatások helyzetéről (Szirmai 2005) ${ }^{2}$.

\section{A meghatározó háttérfolyamatok. A városproblematika jelentősége}

A konferencia szerint a huszonegyedik század a város időszaka lesz, a városi társadalmi létforma egyre inkább általánossá válik. Ezt az is mutatja, hogy míg 1970-ben a világ népességének csak 36,6\%-a élt városokban, addig 1994-ben már 44,8\%-a. A világ népességének fele ma urbanizált környezetben található, noha a különbözó országok között nagyok az urbanizációs különbségek. Az elörejelzések szerint 2025-re a világ népességének $61,1 \%$-a városlakó lesz. A városok között egyre több a hatalmas méretű város, 2000-ben 400 olyan nagyváros volt, ahol a népesség meghaladta az egymillió lakost. 26 olyan megacity van, ahol a népesség száma meghaladja a tízmilliót (Hjerppe 1998). Ezekből 21, vagyis a megavárosok nagy része a kevésbé fejlett régiókban, főként Ázsiában, Latin-Amerikában található (Hjerppe 1998).

A városi társadalmak fejlödésében jelentősek a regionális különbségek, az ebből is adódó differenciált társadalmi, gazdasági és környezeti problémák. Míg az európai városokban jellemzỏ a városi népesség csőkkenése, addig a harmadik világ városainak a népessége hatalmas ütemben növekszik. Európában nincsenek 10 milliós városok, az 5 és 10 millió közötti városok száma öt. Az európai városhálózatban több a kisebb város. A közép-európai városi társadalmak jóval kisebb része él a nagyvárosokban. (Például a cseh városi népesség 16\%-a, a lengyel városi népesség $14 \%$-a, a magyar városi népességének pedig $31 \%$-a lakik nagyvárosokban [Stenning 2004].)

A városi létforma terjedése új típusú társadalmi problémák szervezödésével párosul. A városi és a vidéki térségek közötti társadalmi egyenlötlenségek növekedése, a városi társadalmak belső szegregációja, a városi szegénység (különösen a harmadik világbeli) terjedése, a társadalmi kirekesztés és a kisebbségek, a bevándorlók kủlönbözỏ generációinak az integrációs nehézségei, az ebból adódó társadalmi konfliktusok, illetve konfliktusveszélyek a várospolitikusokat, a várossal foglalkozó szakembereket és a városlakókat - noha eltéró mértékben és differenciált szempontból ugyan, de - nyugtalanítják. Az európai városvezetés számára föként a városcentrumok népességének a csökkenése, a középosztálybeliek kimenekülése okoz gondokat. A szakmai kờzvélemény a várostervezés mai folyamatait, érdekviszonyait bírálja, és a társadalmi (egyben számos szakmacsoport) részvételének a hiányából fakadó problémákat veti fel. A városépítészek, az urbanisztika (föként a középeurópai) képviselói a nem kielégítő rehabilitációs folyamatokat, az épített környezet romlását, a belsô városrészek zöld területeinek a csökkenését bírálják. A városszociológusok a megvalósított rehabilitációt, a dzsentrifikációt követỏ alacsony státuszú népesség kirekesztését látja komoly társadalmi problémának. A város- 
növekedéssel, a szuburbanizációval is összefüggő egyre nagyobb mértékü gépkocsiforgalom, a természeti, környezeti problémák és azok kedvezőtlen egészségügyi hatásai a városlakók és a civil társadalmi szervezetek körében okoznak nagy mértékủ elégedetlenséget. A globális gazdaság, a multinacionális cégek differenciált térségválasztási stratégiái, az ebböl is fakadó városgazdasági szerkezeti nehézségek, a munkanélküliség, a globális és nemzeti, a lokális gazdaság egyenlötlen fejlődési lehetőségei, az ebből is következö függésrendszerek a városok vezetőinek, a vállalkozóknak, a szakembereknek, de a lakóknak is igen nagy problémákat okoznak.

A társadalmi problémák miatt a város az utóbbi évtizedben egyre nagyobb figyelmet kap az Európai Unió kohéziós politikájában, tervezési gyakorlatában is. A városi problémák megoldási törekvései számos európai ország esetében eredményezték a várospolitikai figyelem növekedése mellett a várostudományok megerösödését is. Új várostudományi kutatási központok alakultak meg, egyetemi várostudományi stúdiumok szervezésére, master programok és doktori iskolák megalapítására került sor. Tudományos könyvek sokasága jelenik meg. Kutatói együttmüködések jöttek létre, köztük átfogó nemzetközi kutatások, nemzetközi konferenciák. A Helsinkiben rendezett konferencia is része ennek a folyamatnak, az Európai Unió városi társadalmi problémák kezelésére törekvő új koncepcióinak.

\section{A városkutatásokkal kapcsolatos új módszertani igények}

\section{Az egydimenziós elemzések problematikája}

A városi térségek, a városi társadalmak átalakulása miatt egyre többen javasolják a városkutatások szemléleti módjának fejlesztését, új elméleti modellek megalkotásának szükségességét. Az International Social Science Journal 2004. szeptemberi különszámában, amely az ún. megavárosokkal foglalkozik, Vladimír Kolossov és John. O. Loughlin azt állítják, hogy a világvárosokkal, globális városokkal kapcsolatos nagy elméletek nincsenek empirikusan megalapozva, hogy a világgazdaság és a nagyvárosok közötti kapcsolatokat jelző kritériumok konkrét kutatások keretében nincsenek ellenörizve (Kolossov-Loughlin 2004). A világvárosok ma általában elfogadott rangsorai alapvetỏen szakértői vélekedéseken és nem empirikus vizsgálatokon nyugszanak. Bár újabban vannak ebben kivételek is. Az idézett szerzök Peter Taylor, illetve a Globalisation and World Cities Study Group at the University of Loughborough(GaWC) munkáit említik. Ennek keretében 300 világvárost elemeztek és tipizáltak empirikus eszközökkel, a városok és đ̃lobális gazdasági, üzleti szolgáltatások közötti kapcsolatrendszerek szerint (Kolossov-Loughlin 2004, 414).

A nagyvárosokat ma általában gazdasági, infrastrukturális jellegủ tényezők alapján helyezik el a globális városi rendszerekben. A leginkább használatos mutatók, a nemzetközi közlekedés, és telekommunikációs kapcsolatok, a transznacionális, multinacionális cégek központjainak az elhelyezkedése, a nemzeti piacokhoz történő integráció, a globális munkaerőpiac új területi megoszlása, üzleti és tudásbázisú szolgáltatások, a nemzetközi kapcsolatok, és végül a társadalmi szervezetek területi 
elhelyezkedése, a kulturális innovációk, végül a legfontosabb társadalmi problémák megnyilvánulásai (Kolossov-Loughlin 2004). A felsorolt tényezőkből is jól látszik, hogy társadalmi mutatók alig szerepelnek a vizsgált kritériumok között. Ezt a szempontot többen is hiányolják a mai városkutatásokból. Mattei Dogan tanulmánya szerint például igen nagy probléma, hogy a világváros vagy a globális város koncepciók csak „egydimenziós”, főként gazdasági összefüggésekre koncentráló elemzéseket adnak, s ezek nem elegendỏek a társadalmi valóság értelmezéséhez (Dogan 2004). Véleménye szerint azért sem, mert a 400 gigantikus városban élök nem mindegyikét érintik a globális gazdaság kedvező hatásai. Ezek a hatások alapvetően csak egy meghatározott körre terjednek ki, fóként a gazdasági elitre, illetve a globális gazdasághoz kapcsolódó egyéb társadalmi, szakmai csoportokra. Az itt élők többsége kimarad a nemzetközi kapcsolatok rendszereiből. Véleménye szerint nagyon fontos vizsgálati kérdés például az, hogy az 500 legnagyobb multinacionális cég, a nagy bankok hol helyezkednek el a földrajzi térben. Hiszen a kapitalista rendszer ezzel a kérdésfeltevéssel nagyon jól elemezhető. Ezzel a megközelítési móddal azonban számos egyéb kérdés, közte a városi társadalmi problémák, a városi társadalmi élet legkülönbözőbb feltételei, a városok kulturális és (a gazdaságon kívüli) egyéb szerepei is kívül rekednek a vizsgálatba bevont problémák köréből. A városi társadalmak viszonyairól, közte a városi szegények viszonyairól sincs elegendö ismeret (Dogan 2004).

Az „egydimenziós”, főként gazdasági összefüggésekre koncentráló elemzéseket egy korábbi munka keretében szerzötársaimmal együtt magunk is bíráltuk (SzirmaiA. Gergely-Baráth-Molnár-Szépvôlgyi 2003). A szóban forgó munkában kevésbé teoretikus, inkább szociológiai szempontból leírtuk, hogy meghatározott tudománytörténeti, de föként gazdasági, társadalmi okai, érdek-meghatározottságai vannak az egydimenziós elemzésnck, és az ebböl is fakadó városfejlesztési koncepcióknak.

A világgazdasági szüikségletek teremtették meg (Dogan szóhasználatával) az egydimenziós, gazdasági alapú városelméleteket az 1970-es, és 1980-as években. Ezek az elméletek akkor teljes mértékben relevánsak voltak, hiszen részben kifejezték, részben segítették a világgazdasági egységesülés folyamatait, azok vărosi háttérfolyamatait is kifejlesztették. A volt szocialista országokban az 1990-es évek elején, a gazdasági-társadalmi átmenet időszakában szintén teljes mértékben elfogadottak voltak a globális gazdasági városelméletek, azok megközelítési módjai és az ezekböl is adódó városfejlödési utak is. A kelet- és közép-európai országok számára a globális városokkal való kapcsolat ekkor valóban elsősorban gazdasági szempontból volt fontos. Ebben szerepet játszott az is, hogy a nemzeti politikai elitcsoportok, de az átmenetet vezénylő, és a várossal foglalkozó szakmai csoportok sem tudtak más utat elképzelni, mint a kizárólag gazdasági dinamizmusra alapozott átmenetet, az európai városrendszerbe történő gazdasági integrációt.

A tények szerint ezek az elméletek addig megfelelök, amíg a gazdasági fejlődés szükségletei ezt így kívánják, és amíg nem jönnek létre a paradigmaváltás társadalmi feltételei. A paradigmaváltás társadalmi feltételeit, az egydimenziós megkőzelítés helyett a komplex, gazdasági és társadalmi tényezökre is figyelö felfogást az 
egydimenziós elméleti megközelítés, és az ebböl is következö szük körủ fejlődés, a városfejlesztés kedvezötlen következményei, társadalmi feszültségei és konfliktusai hozzák létre. A verseny és/vagy együttmüködés problémakörét elemzỏ empirikus kutatásokra alapozott munkánkból is láttuk, hogy a gazdaságra alapozott városfejlesztési modellekbe vetett hitet alapvetỏen a városi társadalmak egyre erőteljesebbé váló kritikái, újfajta lakóhelyi, társadalmi igényei rengették meg (Szirmai-A. Gergely Baráth-Molnár-Szépvölgyi 2003).

A paradigmaváltás szükségességét nemcsak az egydimenziós megközelítés és fejlesztés kedvezötlen társadalmi hatásai és a városi társadalmak igényei hozzák létre, hanem a globalizáció, a globális gazdaság kedvezőtlen hatásait bíráló anti-globalizációs mozgalmak, és a baloldali, köztük új-marxista szakmai csoprtosulások kritikái is.

A fejlett országok kutatóinak a felfogásában ma paradigmaváltás játszódik le. A Helsinkiben megjelent, várostudománnyal foglalkozó különböző szakmacsoportok egyértelmủen deklarálták, hogy ma már nem elegendö a várostudományokban a városok és a városfejlödés gazdasági szempontú megközelítése, és nem elegendő a városok gazdasági alapokra helyezett siker-felfogása sem. A társadalmi szempontokat is figyelembe kell venni a kutatásokban, a városi siker meghatározásában is. Miközben a gazdasági és történeti fejlödés alacsonyabb szintjén (a periférián, vagy a félperiférián) elhelyezkedỏ városok (és a szakértők) még mindig nagyobb hangsúlyt fektetnek azokra a városelméletekre, városfelfogásokra, amelyek a gazdasági alapú értelmezésekre, a világgazdasági integráció szüksségleteire épülnek. Ez érdekes módon derült ki a Helsinkiben elhangzott kínai előadásból is. A ma feltörekvő Kína számára a globális városokhoz való gazdasági integráció az egyik leglényegesebb cél.

\section{Konvergencia, divergencia kérdésköre}

Nyilvánvaló, hogy a városnövekedés európai, ázsiai vagy észak- és dél-amerikai modelljei, a kínai városfejlődési folyamatok nagyon differenciáltak, eltéró tényezők határozzák meg, más és más tartalmat jelentenek a történeti, társadalmi folyamatok és a globalizációs hatások szempontjából egyaránt. Josef Gugler a „szegény” országok nagyvárosait összehasonlító módon elemzö, átfogó munkáiban arra az alapvetỏ megállapításra jut, hogy a vizsgált nagyvárosok (Bangkok, Kairó, Hong Kong, Jacarta, Johannesburg, Mexikóváros, Moszkva, Mumbai, Sao Paulo, Szöul, Sanghaj és Szingapúr) sokkal inkább eltérőek, mint hasonlóak. Bár ezek a városok természetesen kifejeznek közös vonásokat is, többek között azért is, mert részei a globális világgazdaságnak, noha csupán „második szintủ játékosok”, pénzügyi és szolgáltatási szerepeik fontosak, parancsnoki funkciókat is betöltenek a globális gazdaságban. De ennél is fontosabb meghatározottságok fakadnak abból, hogy jelentös nemzeti, regionális szerepeket is vállalnak (Gugler 2003). A városok közötti eltéréseket a differenciált történeti háttér, a mai napig érvényes történeti folyamatok, a differenciált gazdasági és politikai körülmények és a sajátos demográfiai hatások, a városi és a vidéki régiók közötti különbségekkel is összefüggő migrációs trendek okozzák és magyarázzák - állítja (Gugler 2004). 
Szirmai Viktória : A városkutatások továbbfejlesztésének szempontjai:

Az európai várostudományok jövője. Tér és Társadalom 19. évf. 2005/3-4. 43-59. p.

Az összehasonlító városkutatásoknak történetileg is visszatérő kérdésfeltevése a hasonlóságok és a különbségek vizsgálata, a divergencia vagy a konvergencia problematikája. Ma mégis mintha több szó esnék a különbségekröl, mint a hasonlóságokról, fontosabb lenne a divergencia, mint a konvergencia feltárása. $S$ bár véleményem szerint mind a két szempont feltárása egyformán fontos, a vonatkozó súlypontok eltolódása kutatásmódszertani kérdésekkel is összefügg. Egyrészt kiderült, hogy sokkal több kutatási ismeret van a városokra általában is jellemzö folyamatokról, mint az eltérésekrỏl. Másrészt azért a meglévő kutatásokból nyilvánvalóvá váltak a lokális meghatározottságú urbánus folyamatok is, világossá vált, hogy a városok között igen sok a különbség, a hasonlóságok mellett igen sok az eltérés is. Az okok között lehetnek a globalizációs folyamatok kedvezötlen hatásai, a városi térben jelentkező társadalmi problémák és konfliktusok, a központi hatalmaknak a problémák kezelésével kapcsolatos sikertelen törekvései is. A központi és a helyi önkormányzatok számára is egyre nyilvánvalóbb, hogy a városi problémák csak a helyi civil társadalmak részvételével kezelhetők. Ehhez szükség volt a civil társadalmak megerősödésére, a városi társadalmaknak a globálissal szembeni ellenállására is, ezzel összefüggésben a globalizáció-ellenes mozgalmak, valamint olyan szakmacsoportok megjelenésére, melyeknek tagjai a lokális folyamatok, a történeti kondicionáltságok megismerését a korábbiakhoz képest sokkal fontosabbnak tartják. A Helsinkiben rendezett konferencia erre is jó példa, az elöadók közül többen is említették a városi társadalmi, gazdasági különbségek, a történeti tényezők jelentőségét.

\section{Európai városi problémák és kutatási témák}

Az európai városkutatások tematikus elemzése kétség kívül meghaladná a tanulmány kereteit. A „Forward Look in Urban Science, Final Conference” előadásaiból, illetve a megalapozó workshopok által bemutatott kutatási eredményekből az látszik, hogy a legfrissebb kutatások a nagy társadalmi-gazdasági változásokkal, az urbanizáció legújabb trendjeivel, a globális gazdaság területi és társadalmi hatásaival, a nagyvárosi társadalmak strukturális átalakulásával, a térbeli társadalmi problémákkal és konfliktusokkal foglalkoznak.

A 2004. június 11-12.-én Párizsban megrendezett találkozó fö kérdése az volt, hogy milyen városi társadalmak szervezödnek a mai Európában? A vita során a város társadalmi szövetének az átalakulása, a történeti okokkal is összefüggö egyenlőtlenségek derültek ki. A közvetlen emberi kötỏdések, a szomszédságok szerepének a fontossága, a társadalmi kohézió szükségessége is megfogalmazódott. A bevándorlók integrációs problémái, a kirekesztés jelenségei, a bevándorlók paszszív politikai részvétele a társadalmi participáció jelentőségére mutattak rá.

A társadalmi részvétel problematikája a közterek funkcióinak alakulásával is öszszefügg. A közterek történetileg mindig is fontos szerepeket töltöttek be a városok társadalmi életének formálásában, a társadalmi integrációban. A Helsinkiben megrendezett zárókonferencián érdekes angol esettanulmány hangzott el a régi ipari városok közterületeinek átalakulásáról, új funkcióinak megjelenésérỏl. Az eset- 
tanulmány szerint a telekprivatizáció következtében átalakult a közterületek közösségi használhatósága, a korábban szabad közterületen megjelenő magánterületek tiltó táblái fokozatosan kiszorítják az embereket az addig szabadon használt közterületekről, létrehozva ezzel a bennmaradottak, illetve a kirekesztettek új, egyben egyenlötlen világát (Muir 2005).

Az építészek szerint a városközpontok átalakulása, a ,citysedés” folyamata a globális gazdaság hatalmi törekvéseinek építészeti jellegzetességekben, toronyházakban, a mai modern építőanyagokban való megjelenésével kapcsolatos. A globális gazdaság terjedésével a városközpontokban új intézmények, bankok, irodák, luxuslakások jelennek meg. Egy Helsinkiben elhangzott előadás, a berlini Potsdam-teret, mint a globális gazdaság piacát, befogadó terét mutatta be, a kapcsolódó bevásárló központokkal és a fogyasztókat vonzó showmüsorokkal, mindazokkal tehát, amelyek nemcsak eladhatóvá teszik a modern piacgazdaság termékeit, hanem amelyek átalakítják, új funkcionális és társadalmi tartalommal töltik be a közösségi tereket (Lehrer 2005).

A városi élet kockázatait és a társadalmi sérülékenységet 2004. június 24. és 27. között Lipcsében vizsgálták meg egy másik workshop keretében. A kutatások szerint az európai városokban, de kiváltképp a harmadik világ városaiban kialakuló szegénység, az egyenlötlenségek élezödése, a társadalmi konfliktusok, a modern, globális városi bünözés, a városi élettel összefüggő stressz és az egészségügyi problémák jelentős mértékben növelik a városi életforma kockázatait. A nagyvárosi élet ma egyik legnagyobb kockázatát a terrorizmus jelenti. Ezért is kísérte kiemelt figyelem Harvey Molotch Helsinkiben tartott elöadását. Az elöadó szerint a világ szinte egyforma repülőterei nemcsak a globális gazdasági szereplök kommunikációs, kapcsolódási tereit hozták létre, hanem a globális gazdaságpolitika hatalmi viszonyait, domináns törekvéseit, köztük az amerikai politikai és gazdasági befolyást is kifejezik. A nagyvárosokhoz kapcsolódó repülőterek és az utasszállító gépek többnyire az amerikai technikát és gazdasági hatásokat közvetítik. Ezek a terek azonban a nemzetközi terrorizmus terjedéséhez is hozzájárulnak, hiszen a mai repülőterekhez kapcsolódó biztonsági rendszerek is a globális világpolitikai beállítottságát fejezik ki, az érintett civil társadalmak szempontjai és a differenciált veszélyezettségei, az ebből is fakadó differenciált (például a gyerekekre, az idősebbekre is figyelő) védelem ezekből a terekből teljesen hiányzik. (Molotch 2005).

A társadalmi megalapozás, a lokális szempontok érvényesítésének a gondolata nemcsak a terrorizmus elleni védelmi rendszer összefüggésében merült fel. A városi kockázatok lehetséges érintettjeinek a védelme érdekében egy olyan új típusú városi térkép készítését javasolták, amely összegyüjti, és térképre viszi a társadalmi szempontból különösen sérülékeny városrészeket és azok lakosságát, a veszélyeztetett csoportok körét. Ezzel is biztosítva a várospolitikai figyelmet, az ahhoz szükséges monitoring rendszer kialakítását is. ${ }^{3}$

2004. szeptember 17-18.-án Prágában rendezték meg azt a szakmai találkozót, ahol a városi civilizációs problémákról volt szó. A fỏ kérdés az volt, hogy az európai városok fejlödésében milyen szerepet játszik a kultúra, a kulturális aktivitások. Továbbá, hogy mit jelent a sikeres városfejlődés, milyen tényezők játszanak szerepet a 
városok közötti versenyben. A munkacsoport legfontosabb megállapítása az volt, hogy a sikeres városi fejlödés csak komplex módon képzelhető el. Ennek értelmében egyensúlyra kell törekedni a gazdasági versenyképesség, a társadalmi kohézió és a fenntartható fejlödés szempontjai között. Többek között azért is, mert az igazi versenyképességet az üzleti világ és a magánélet közös sikeressége adja. A résztvevők megfogalmazták, hogy új európai paradigmák fejlődése tapasztalható, a sikeres (successful) város fogalmát egyre inkább a közösségi (good) város fogalma váltja fel.

A közösségi város fogalma a társadalmi kontroll és a társadalmi részvétel problematikáját is felveti. Ki, illetve kik irányítják a városok fejlődését, mely szereplők azok, amelyek ma részt vesznek a városi folyamatok szabályozásában, a kialakult társadalmi problémák enyhítésében? Az európai demokratikus rendszerekben cél a városi társadalmak, az összes érintett társadalmi szereplő részvétele, a helyi, illetve a központi kormányzatok differenciált szerepvállalása mellett.

A különböző kutatások szerint a modern nagyvárosi fejlődés fontos szereplöi, társadalmi és politikai értelemben is irányító tényezöi a multinacionális cégek. A nagy nemzetközi cégek elsősorban gazdasági érdekeik és funkcióik miatt jelennek meg a nagyvárosi terekben, hiszen azok biztosítják a müködésükhöz szükséges infrastruktúrát, munkaerőt. A multinacionális cégek központjai parancsnoki funkciókat is betöltenek, s bár ezek a funkciók többnyire a nagyvárosi terek határain, az országok határain is túllépnek, hiszen a leányvállalatok többnyire máshol találhatóak. Mégis befolyásolják az adott városok, várostérségek hatal mi viszonyait, nemcsak a befizetett adóikkal, hanem részben politikai befolyásukkal, gondoljunk a nemzetállamokkal való sajátos viszonyukra, a nemzetállamok fokozatos kiszolgáltatottságára (Sassen 2000). A nagy cégeknek vélhetőn erős társadalmi és politikai kontroll lehetöségét kínálja az a tény, hogy a városi társadalom jelentős részének (sokszor éppen a társadalmi gazdasági modell múködése szempontjából lényeges csoportoknak, ha nem is a legjobb feltételekkel, de) munkát kínálnak, s hogy a városi elit (vélhetően) legbefolyásosabb csoportjait integrálják.

A helsinki konferencián elhangzott kínai elöadás az európaitól eltérő helyzetre, az állam növekvő politikai és társadalmi befolyására mutatott rá. A 19. századi Kína a világ legkevésbé urbanizált térsége volt. $\mathrm{S}$ bár ma a városi népesség koncentrációja a világ urbanizációs szintjéhez képest még mindig alacsony (26\%), Kínában rendkívül dinamikus urbanizáció zajlik le. A kínai nagyvárosok egyre fontosabb szerepeket töltenek be a globális városhierarchiában, a regionális jelentőségük is számottevő (Smith 2004). Az állam erőteljes mértékben támogatja az urbanizációt, egyrészt azért, hogy ezzel is gyorsítsa a globális gazdasági integrációt, másrészt pedig azért, hogy biztosítsa a gazdaságilag és társadalmilag növekvő jelentőségű várostérségek állami politikai kontrollját (Wing-shing 2005).

A globális gazdaság terjedésével összefüggỏ modern kolonializáció szempontjait vetette fel egy másik elöadás, amely az afrikai nagyvárosok, köztük kiemelten Johannesburg társadalmi átalakulását, a jellemzö térbeli társadalmi egyenlőtlenségeket mutatta be (Mabin 2005). 
Az ún. „szegény” országok elemzésekor a Josef Gugler által szerkesztett kötet is foglalkozik Johannesburggal, amely Dél-Afrika igen fontos városrégiója (Crankshaw-Parnerl 2004). A johannesburgi esettanulmányból kiderül, hogy az etnikailag és faji hovatartozás szerint történetileg mindig is vegyes városi társadalomban az állam diszkriminatív politikái miatt a fehérek és a feketék közötti egyenlötlenségek hosszú időn keresztül sokkal jellemzöbbek voltak, mint a fajokon belüli társadalmi egyenlőtlenségek. A legújabb, demokratikusan megválasztott kormány kevésbé diszkriminatív politikája óta a helyzet megváltozott, csökkentek a fehérek és a feketék közötti egyenlötlenségek, miközben élesebbé váltak a feketék közötti társadalmi differenciáltságok. A kialakult helyzetnek két fô oka is volt. Az utóbbi évtized demográfiai adatai szerint 1940 és 2000 között a johannesburgi városi térségben megfigyelhető volt az afrikai népesség hatalmas mértékủ növekedése, a fehér lakosság arányának fokozatos csökkenése. Az afrikai népesség azonban szelekciós mechanizmusokon, a várospolitika adminisztratív szabályain keresztül áramlott be a nagyvárosba. A lakáspolitika csak azoknak az afrikai, egyben valamilyen szinten képzett munkásoknak a városba költözését támogatta, akik a johannesburgi régióban szullettek, a többiek, föként a szakképzetlenek, csak munkát vállalhattak, munkásszállásokon lakhattak, a családjuk a vidéki térségekben maradt. Ezzel létrehozták az „urbanizált” és a „vándorló” afrikaiak közötti társadalmi ellentmondásokat (Crankshaw-Pamerl 2004).

A fejlődő országok sokaságában figyelhető meg hasonló jelenség, a vidéki népesség egyre növekvő mértékü nagyvárosi térségekbe történő áramlása. Ezzel kapcsolatban Mattei Dogan a tanulmányában (Dogan 2004) ugyanazt kérdezi, amit demográfusok, szociológusok, közgazdászok sokasága kérdez: miért vándorolnak e nagyvárosokba a vidéki lakosság milliói? Vélhetőleg azért - állítja -, mert még mindig jobbak a megélhetési esélyeik a városokban, a városok környékén, mint a falvakban (Dogan 2004, 355). Dogan szerint a tények azonban azt mutatják, hogy ezek az emberek többnyire nem találják meg a számításaikat, hiszen a megavárosok perifériáin növekszenek a fizikailag és társadalmilag egyaránt leromlott negyedek, a slumök, a „bidonville”-ek. Ezért is jogos az a dogani kérdés, miért nincsenek forradalmak, csak elszórt kisebb összeütközések jönnek létre ezekben a városokban, ahová az elkeseredett vidéki lakosság tömegesen költözik be, megélhetést és lakást keresve? John Walton szerint azért, mert a városi tiltakozó akciók nem rendelkeznek átfogó ideológiai irányokkal, a megmozdulások célja inkább figyelemfelkeltés, mint a forradalom kirobbantása (idézi: Dogan 2004, 354-355). Bizonyára a városi társadalmak mai hatalmi szerkezete, az egyéni és közösségi függési rendszerek is meghatározzák a kialakult helyzetet. Az országonként eltérő jellegü hatalmi és politikai kontroll, az állam nagyvárosokba allokált szervezetei, az önkormányzatok és a multinacionális és egyéb nagyobb cégek közös változatásellenes érdekviszonyai, a munkavállalók helyzetbeli (jövedelmi, hatalmi) megosztottsága, a közösségi szerveződés hiánya is hozzájárulnak ahhoz, hogy a fejlödő országok nagyvárosi munkássága nem lázad fel a helyzete ellen. 


\section{Városi problémák és kutatási témák Magyarországon}

Az 1990-es évek elején a hazai városkutatások többsége a rendszerváltás folyamataira koncentrált. A kutatások célja egyrészt azt volt, hogy feltárják a centralizált politikai és társadalomirányítási modell válságának következményeit, másrészt az, hogy megvizsgálják a piacgazdaság és az új városi társadalmak kialakulásának az összefüggéseit, valamint a nyugat-európai városrendszerbe történő integráció kibontakozásának a feltételeit (Enyedi 1998). Ebben az időszakban számos kutatási eredmény született a lakás- és telekprivatizációs folyamatok hatásairól, a centralizált lakásszektor átalakulásáról, az új lakáspiaci formák kialakulásáról, a lakáspiac átalakulásával kapcsolatos lakásmozgalmakról, társadalmi konfliktusokról is (Hegedüs-Tosics 1998; Györi-Matern 1997).

A városok rendszerének átalakulása, az új városi funkciók kialakulása, a városhierarchiát újonnan megszabó tényezök, az európai városrendszerbe való integráció szempontjainak a feltárása (Beluszky 2000) mellett nemzetközi összehasonlító vizsgálatok is születtek az ún. szocialista új városok és a régi városok viszonyairól, a hasonlóságot és a különbségeket bizonyító tényezökröl, (Szirmai 1998; HaumontJalowiecki-Munro-Szirmai 1999), továbbá a hazai iparvárosok átalakulásáról (Germuska 2004). A városi gazdaságok átalakulása, a helyi gazdaságok szerveződése, a transznacionális és multinacionális vállalatok, a külföldi múködö tőke érkezésének városfejlesztỏ hatásai számos kutatás tárgya volt (Nagy 2004; Rechnitzer 1993).

A városok társadalmi és gazdasági átalakulásában betöltött vezető szerepe miatt Budapeströl igen sok kutatás készült. Ezek között több olyan összegző munka is megjelent, amely a fỏváros gazdasági és társadalmi strukturális átalakulását, a történeti hátteret egyaránt bemutatta (Enyedi-Szirmai 1992; Ladányi-Szelényi 1997). Konkrét kutatási eredmények vannak a fövárosi társadalmak átalakulásának a folyamatairól, a térbeli társadalmi elkülönülés történetileg is meghatározott formáiról, a legújabb szegregációs trendekről is (Csanádi-Ladányi 1992).

Több kutatás is foglalkozott a budapesti agglomeráció átalakulásával, a városcentrum és a környék gazdasági szempontú kapcsolatrendszereivel, a globális gazdaság, a multinacionális cégek telephelyválasztási stratégiáinak térségfejlesztő hatásaival (Izsák 2003; Diczházi-Matolcsy 1997). Budapest közép-európai régióban betöltött új nemzetközi szerepeinek az elemzésére egy átfogó akadémiai kutatás keretében került sor (Barta-Enyedi-Glatz 1998). A budapesti városfejlódési folyamatokkal, a meghatározó érdekviszonyokkal több kutatás is foglalkozott. Az 1990-es évek elején empirikus kutatás készült a budapesti várospolitika európai integrációs stratégiájáról, Budapest, Bécs és Pozsony lehetséges együttmüködését meghatározó érdekviszonyokról (Faymann-Szirmai 1993). 2003-ban empirikus kutatás elemezte a globális gazdaság érdekviszonyaival összefüggő városfejlödési folyamatokat, a belső egyenlötlenségeket, a globális hatásokat differenciált módon közvetítő építészet és várostervezés szerepeit, érdekviszonyait is (Szirmai-Baráth 2003). Kötetek jelentek meg Budapest jövőbeni lehetséges fejlesztési stratégiáiról is (LukovichCsontos 2002; Vidor 2005). 
Az 1990-es évek második felében a városkutatások figyelme egyre inkább a globalizáció problémái, a globális gazdaság városfejlödési hatásai felé fordultak. A témához kapcsolódó kutatásokból egyrészt kiderültek a külföldi működö tőke érkezésének a regionális és városfejlődésre gyakorolt pozitív következményei, a városfejlődést dinamizáló tényezők, a szerkezetváltás folyamatai, másrészt nyilvánvalóvá váltak a külföldi müködő tőke érkezéséből fakadó városi egyenlőtlenségek is, a centralizált területi fejlődés sajátosságai, a városok előnyei, és a belső differenciáltságok is (Keune-Nemes Nagy 2001).

A világgazdaság átalakulásának nagy trendjei, ezek Budapest fejlödésére gyakorolt hatásai is kiderültek (Cséfalvay 1999). A külföldi müködő tőke érkezésének várható jövőbeni tendenciáiról is készülttek kutatások. Ezekböl a meglévő városi gazdasági és szolgáltatási előnyök hatása derült ki. S ez azt a feltevést kínálja, hogy vélhetően a jövőben tovább növekednek a városi és a falusi térségek, a nagyobb és a kisebb városok közötti gazdasági és fejlödésbeli egyenlőtlenségek (BartaBernek-Nagy 2003). A legújabb regionális gazdasági kutatások szintén ezt a tendenciát igazolják, a külföldi müködőtőke-befektetések területi elhelyezkedése továbbra is rendkívül koncentrált, ebben nincs változás az utóbbi néhány évben (Antalóczy-Sass 2005).

A hazai szakirodalom szerint a városi, a térségi gazdaság fejlődése számára rendkívül fontos a külföldi vállalatok térségi, lokális beágyazottsága. Ennek révén jobban integrálódik a tőke, illetve ez biztosítja a magyar vállalatok hosszú távú fejlödését (Barta 2002). A magyar szakirodalomban vitatott a globális gazdaság térségi integrációjának a problematikája. Ezért is fontos a multinacionális cégek és a városi társadalmak viszonyának a vizsgálata. A Székesfehérvár vizsgálatból kiderültek az elzárkózás jelenségei, az ezzel kapcsolatos társadalmi konfliktusok is, de az integráció folyamatai is (Szirmai-A. Gergely-Baráth-Molnár-Szépvölgyi 2003).

A városverseny problematikája szintén fontos kutatási téma volt. Számos kutatás foglalkozott az európai városversenyben való részvétel feltételeivel, a városok versenyében elérhető siker problematikájával is. A kutatásokból kiderülnek a sikeres városverseny gazdasági, infrastrukturális, intézményi és társadalmi feltételei, a gazdasági sikeresség mellett a társadalmi sikeresség kritériumai is (Enyedi 1997; Lengyel-Rechnitzer 2000; Szirmai-A. Gergely-Baráth-Molnár-Szépvölgyi 2003; Timár-Velkey 2003). Nyilvánvalóvá váltak a városversenyben elfoglalt pozíció meghatározó tényezői is, a földrajzi, illetve a regionális helyzet, a nemzeti és a térségi, helyi várospolitikák jellegzetességei, a városi társadalmak jellegzetességei, a makrogazdasági és társadalmi körülmények (Nemes Nagy 2000, 2001), továbbá az összefüggések a városok innovációs potenciálja és a városversenyben való részvétel között (Rechnitzer 1993).

$\mathrm{Az}$ adott téma keretében egyre fontosabb kérdésként merül fel a kommunikációs és információs rendszerek, valamint a technológia szerepe. Ennek keretében számos esettanulmány készült a magyar városhálózat info-kommunikációs helyzetéről, a városok szerepéről az információs társadalom építésében és a versenyképességben is (Horváth-Rechnitzer 2004). 
Szirmai Viktória : A városkutatások továbbfejlesztésének szempontjai:

Az európai várostudományok jövője.Tér és Társadalom 19. évf. 2005/3-4. 43-59. p.

A rendszerváltás keretében, a piacgazdaságra való áttérés során, a globális gazdasági hatások eredményeként is a városi térségekben egyre nyilvánvalóbbá váltak a társadalmi feszültségek, az új térbeli társadalmi egyenlötlenségek is. Ezért növekednek a városi, a várostérségi társadalmi problémák feltárására törekvö vizsgálatok. Ezekből kiderült, hogy az utóbbi évek során erösödött a térbeli, közte az etnikai szegregáció (Csanádi-Ladányi 1992; Szelényi 1987; Ladányi-Szelényi 2002). Több kutatás is igazolta a budapesti térbeli társadalmi szerkezet globális gazdasági hatásokkal is összefüggő átalakulását (Kovács 2004). Kiderültek az új társadalmi polarizáció jellegzetességei, a hasonlóságok és a különbségek a magyar főváros, Prága és Varsó esetében (Weclawowicz 1998). Továbbá a magyar és az európai városi terek társadalmi szerkezetének főbb sajátosságaiban érzékelhető közeledés trendjei is (Szirmai 2004). A rendszerváltás óta vitatott a nagy lakótelepek sorsa, társadalmi átalakulása. A kutatásokból igazolódtak a differenciálódás folyamatai, a társadalmi problémákat (történeti okok miatt is) jelentős mértékben koncentráló lakótelepek feszültségei, de a megújulás jelenségei is (Csizmady 2003; Szemzö-Tosics 2003).

$\mathrm{Az}$ egyik legújabb városkutatási projekt, amelynek a címe „Várostérségek, térbeli társadalmi egyenlötlenségek és konfliktusok, az európai versenyképesség térbeli társadalmi dimenziói" interdiszciplináris módszerekkel (köztük 5 ezer fóre kiterjedó reprezentatív kérdőíves szociológiai felvétellel) vizsgálja meg a nyolc (100 ezer fönél nagyobb népességú) nagyváros és Budapest térbeli társadalmi szerkezetét, az egyenlőtlenségek társadalmi hatásait, a konfliktusokat generáló következményeit. ${ }^{4}$

Az 1990-es években fokozatosan érzékelhetővé váltak a városok belső gazdasági és társadalmi kuilönbségei. A várost fejlesztő gazdasági folyamatok alapvetően a belsỏ városrészeket és a városkörnyéket, az elővárosi zónát (annak meghatározott részeit) érintették. (Ez utóbbiak jelentős mértékben az ipari parkok, a kereskedelmi szolgáltatások, a logisztikai centrumok révén dinamizálódtak). A jövedelmek növekedése és a belvárosi környezeti problémák következtében a belvárosi középosztály tagjai közül egyre többen költöztek ki a városkörnyéki településekre. Ez is segítette a városkörnyék fejlödését. A városközpontokat környezó belsô lakóhelyi övezeteket, a korábbi ipari funkciókat betöltö ún. barna zónákat és a nagy lakótelepek többségét azonban elkerülték a fejlödés folyamatai. Mindezek hatására egyre tỏbb olyan városrész jött létre, ahol a fizikai és a társadalmi leromlás jelei egy időben jelentek meg. Nem véletlen tehát, hogy növekszik azoknak a kutatásoknak, illetve projekteknek a száma, amelyek a belvárosi társadalmi problémákkal, a rehabilitációs folyamatokkal, azok társadalmi következményeivel, köztük a társadalmi fenntarthatóság problémájával foglalkoznak. A kutatásokból főként a Budapestre jellemző várospusztulás jelenségei derülnek ki, a fizikai és társadalmi problémák koncentrálódásának folyamatai, valamint a városfelújítás állami és piaci meghatározottságai (Lichtenberger-Cséfalvay-Paal 1994). A slumként nyilvántartott területek lakossága társadalmi helyzetének a feltárására, a szanálással kapcsolatos beállítottságok vizsgálatára szintén Budapesten került sor (László-Tomay 2002). A Városkutatás Kft. átfogó tanulmányt készített a szociális városrehabilitáció koncepciójának, a szükséges eszközrendszerek megalapozására (Gerőházi 2004). 2004-ben a MUT 
átfogó projektet indított a rehabilitáció környezetvédelmi, építészeti, gazdasági, táji és társadalmi szempontú elemzésére, a kapcsolódó kutatások összegzésére is. A budapesti barnaövezet megújulási esélyeit az akadémiai Stratégiai Kutatások keretében vizsgálták átfogó módon (Barta 2004). Egy nagy nemzetközi összehasonlító projekt keretében került sor néhány budapesti leromlott városnegyedben a lakáspolitikák és a társadalmi kirekesztés összefüggéseinek a vizsgálatára (Jensen et al. 2004). A problémák kezelésével összefüggésben merült fel a társadalmilag fenntartható városfejlödés igénye, ennek keretében a társadalmi rész vétel szükségessége (Enyedi 2004).

\section{Összegzés: a jövóre vonatkozó kutatási javaslatok}

A helsinki konferencián elhangzott elöadásokban és a vitákban, valamint a jövőbeni legfontosabb új kutatási irányok megfogalmazásakor egyaránt kiemelt figyelmet kaptak a városi társadalmi problémák. A konferencia résztvevői között megegyezés alakult ki abban, hogy a városi kutatások keretében egyre nagyobb hangsúlyt kell fektetni a városi lakosság szempontjaira, a társadalmi összefüggések feltárására. Ennek keretében a városi népesség életkörülményeinek, életformáinak, kulturális szokásainak az elemzésére, a városi társadalmi egyenlötlenségek vizsgálatára, a társadalmi kirekesztés, a szegregáció folyamatainak a feltárására, a gazdasági és a társadalmi versenyképesség komplex értelmezésére, a társadalmi kohézió erősítésére is.

A konferencián részvevők egyetértettek abban, hogy erösíteni kell az összehasonlító elemzéseket, és fel kell tárni az európai, az amerikai és az ázsiai városok közötti különbségeket és hasonlóságokat is. A kutatásmódszertani problémák tisztázásának is nagyobb figyelmet kell szentelni. Egyetértés volt a különböző módszerek együttes alkalmazásának a szükségességében, a globális és a lokális, az elméleti és az empirikus kutatások közös alkalmazásának a fontosságában, az interdiszciplináris kutatások jelentőségében.

A konferencia társadalmi szemlélete és beálítottsága talán a legfontosabb újdonság volt. A kialakult helyzetnek nem lehetett oka a városszociológusok túlsúlya. Már csak azért sem, mert nem voltak többen az egyéb szakmacsoportokhoz képest. A társadalmi szemlélet erősödésének sokkal inkább egy olyan általános felismerés volt az oka, hogy a városi terek konkrét társadalmi és gazdasági problémái, a kapitalista társadalmi modell válsága, a globalizáció kedvezötlen következményei, a történelmi elmaradottságok problémái a hagyományos módon, vagyis a társadalmi eszközök nélkül, a döntési folyamatokból eddig kimaradt civil társadalmi szereplök, a városi társadalom részvétele nélkül kezelhetetlenek.

Ez a felismerés a mai magyarországi kutatásokban is megjelent. A magyar városkutatók szerint mindenekelőtt erösíteni célszerü a nemzetközi összehasonlító kutatásokat, fel kell tárni a közép- és a nyugat-európai városfejlödési trendeket, a különbségeket és a hasonlóságokat, a meghatározó tényezöket. Az európai városhálózat átrendeződését, a regionális központok új szerepeit, az európai integráció várostérségi társadalmi következményeit. Többen javasolták a különböző várostípusok komplex gazdasági és társadalmi elemzését, a fizikailag és társadalmilag különösen 
problematikus terek, a nagy lakótelepek, a leromlott belvárosi negyedek társadalmi folyamatainak a feltérképezését, a rehabilitáció jövőbeni alakulását is. A magyar városkutatók fontosnak tartották a térbeli társadalmi szegregáció átfogó vizsgálatát, a társadalmilag fenntartható városfejlödés feltételeinek a tisztázását, a civil társadalom, a szomszédsági egységek várostervezésben, városfejlesztésben betöltött szerepeinek az elemzését is. A várospolitika és a civil társadalom kapcsolatrendszereinek az elemzését is nagyon időszerü kutatási témának tartották.

A közös felismerés oka az európai és hazai tudományos együittmúködések hosszú történeti hagyományain túl alapvetően talán mégis a konvergencia jelensége, az a tény, hogy a magyarországi városfejlődési folyamatok alapvetỏen az európai és a globális hatásoknak megfelelően alakulnak, hogy hasonló társadalmi, gazdasági, politikai mechanizmusok formálják a városi társadalmi teret, miközben nyilvánvalóak a belső eltérések, a történeti társadalmi kondicionáltságok is.

Véleményünk szerint valójában nincs igazán különbség a hazai és az elemzett európai városkutatások tematikájában. Talán a hangsúlyokban, a gazdasági, illetve a társadalmi szempontokra koncentrálás történeti eltéréseiben érzékelni eltéréseket. A közép-európai megkésettség, az államszocializmus válsága, a rendszerváltás szükségletei miatt az átmenet kibontakozásakor nagyobb kutatási figyelmet kaptak a gazdasági válság kezelésével, a gazdasági modernizációval és a globális integrációval összefüggö jelenségek. Ma már érzékelhetỏ a gazdasági és a tảrsadalmi folyamatok iránti komplex figyelem. A magyar városkutatások - ahogy az európai öszszehasonlító városkutatások is - a jövöben egyre nagyobb mértékben az Európai Unió városkutatási politikája és kutatási támogatási rendszere szerint alakulnak, a hazai kutatási támogatási rendszerek mellett. Ennek alapján jogos az a feltevés, hogy hosszú távon még eröteljesebb hasonlóság várható a magyar és az európai városkutatások, a várostudományok jövőbeni alakulásában, többek között az egyre bővülő kutatási együttmúködések alapján is.

\section{Jegyzetek}

${ }^{1}$ A Szerzö az Alapítvány meghívására és annak támogatásával vett részt a rendezvényen.

${ }^{2}$ A megalapozó anyag az utóbbi 15 esztendỏ - fơként idegen nyelven publikált - főbb városkutatási témáit, a témákat meghatározó föbb városi problémákat elemzi, és javaslatokat ad a jövőben szükséges kutatási irányokról. A javaslatok kidolgozásához segitséget kértem a hazai városkutatók nagy többségétől. Ezt ezúton is köszönöm.

3 A vărostérségek társadalmi egyenlötlenségeit feltåró NKFP kutatásban mi is gondoltunk hasonló jellegü szociális térkép kialakításăra. Meg is kezdödőtt az ezzel kapcsolatos megalapozó munka.

${ }^{4}$ A kutatást az NKFP támogatja. A projekt megvalósítására szerveződött konzorcium központja az MTA Szociológiai Kutató Intézet. Témavezető: Szirmai Viktória. 


\section{Irodalom}

Alan Mabin, A. (2005) African Cities. (Konferencia elöadás) Helsinki, Finland.

Antalóczy K.-Sass M. (2005) A külföldi müködőtöke-befektetések regionális elhelyezkedése és gazdasági hatásai Magyarországon. - Közgazdasági Szemle. Május. 494-520. o.

Barta Gy.-Bernek Á.-Nagy G. (2003) A külföldi müködötőke-befektetések jelenlegi tendenciái és területi elmozdulásának esélyei Magyarországon. - Tér és Társadalom. 4. 173-190. o.

Barta Gy. (2002) A magyar ipar területi folyamatai. Dialóg Campus Kiadó, Budapest-Pécs.

Barta Gy. (szerk.) (2004) A budapesti barnaövezet megújulási esélyei. MTA Társadalomkutató Központ, Budapest.

Beluszky P. (2000) Adalékok a városállomány 1990 utáni átalakulásához. Horváth Gy.-Rechnitzer J. (szerk.) Magyarország területi szerkezete és folyamatai az ezredfordulón. MTA Regionális Kutatások Központja, Pécs. 115-130. o.

Crankshaw, O.-Parnerl, S. (2004) Johannesburgrace, inequality, and urbanisation. Gugler, J. (2004) World Cities Beyond the West, Globalisation Development and Inequality. Cambridge University Press, 348-371. o.

Csanádi G.-Ladányi J. (1992) Budapest térbeni-társadalmi szerkezetének változásai. Akadémiai Kiadó, Budapest.

Cséfalvay Z. (1999) Helyank a nap alatt, Magyarország és Budapest a globalizáció korában. Kairosz Kiadó, Nóvekedéskutató.

Csizmady A. (2003) A lakótelep. Gondolat, Budapest.

Dicházi B.-Matolcsy Gy. (1997) Budapest újjászuiletése. - Valóság. 9. 36-47. o.

Dogan, M. (2004) Introduction four hundred giant cities atop the world. - International Social Science Journal, Mega-cities. 181.347-361. o.

Enyedi Gy.-Szirmai V. (1992) Budapest a Central European Capital. Belhaven Press a division of Pinter Publishers LTD, London.

Enyedi Gy. (1997) A sikeres város. - Tér és Társadalom. 4. 1-9. o.

Enyedi, Gy. (1998) Social Change and Urban Restructuring in Central Europe. Akadémiai Kiado, Budapest.

Enyedi, Gy. (2004) Public Participation in Socially Sustainable Urban Development. Pécs.

Faymann, S.-Szirmai, V. (1993) Budapest: géopolitique et developpement urbain. Act Consultants, Paris.

Germuska P. (2004) Indusztria büvöletében. Fejlesztéspolitika és a szocialista városok. 1956-os Intézet, Budapest.

Gerőházi É.-Somogyi E.-Stömpl P.-Szemző H--Teller N.-Tosics I. (2004) A szociális városrehabilitáció: koncepció, eszközrendszer és modellkisérletek. Kézirat. Városkutatás Kft, Budapest.

Glatz F.-Barta Gy. (szerk.) Enyedi Gy. (programvezető) (1998) Budapest - nemzetközi város. Magyar Tudományos Akadémia, Budapest.

Gugler, J. (2003) World Cities in Poor Countries: Conclusions from Case Studies of the Principal Regional and Global Players. - International Journal of Urban and Regional Research. 3. 707-712. 0.

Gugler, J. (2004) World Cities Beyond the West, Globalisation Development and Inequality. Cambridge University Press.

Györi P.-Matern É. (1997) Housing movements in Budapest. - Pickvance, K.L.-Manning, N.-Pickvance, Ch. (eds.) Environmental and Housing Movements. Avebury, Aldershot, England. 89-143. o.

Haumont, N.-Jalowiecki, B.-Munro, M.-Szirmai, V. (1999) Villes nouvelles et villes traditionelles. Une comparaison internationale. Edition l'Harmattan, Paris.

Hegedús, T.-Tosics, I. (1998) Towards New Models of Housing System. - Enyedi, Gy. (ed.) Social Change and Urban Restructuring in Central Europe. Akadémiai Kiadó, Budapest. 137-169. o.

Hjerppe, R. (1998) Urbanisation: Its Global Trends, Economics and Governance, Government Institute for Economic Research. UNU/WIDER, The Finnish Ministry of the Environment, Helsinki.

Horváth Gy.-Rechnitzer J. (2004) A vezetö magyar városok innovációs kapacitása és fejlesztési elképzelései. MTA RKK NYUTI, Gyôr.

Izsák É. (2003) A városfejlödés természeti és társadalmi tényezöi: Budapest és környéke. Napvilág Kiadó, Budapest.

Jensen, A.H.-Kährik, A.-Liias, R. (2004) New Ideas For Neighbourhoods In Europe. University of Bergen, TUT Press, Bergen.

Keune, M.-Nemes N.J. (szerk.) (2001) Helyi fejlödés, intézmények és konfliktusok a magyarországi átmenetben. ELTE TTK Regionális Földrajzi Tanszék, Budapest. 
Kolossov, V.-Loughlin, J.O. (2004) How Moscow is becoming a capitalist mega-city. - International Social Science Journal. 181.413-429. o.

Kovács Z. (2004) A budapesti barnaöv lakófunkciójának helyzete és fejlesztési lehetőségei. - Barta Gy. (szerk.) A budapesti barnaövezet megújulási esélyei. MTA Társadalomkutató Központ, Budapest. 109-129. o.

Ladányi J.-Szelényi I. (1997) A társadalom etnikai, osztály- és térszerkezetének összefuiggései az ezred. forduló Budapestjén. - Kárpáti Z. (szerk.) Társadalmi és területi folyamatok az 1990-es évek Magyarországán. MTA Társadalmi Konfliktusok Kutatóközpontja, Budapest. 85-96. o.

Ladányi J.-Szelényi I. (2002) Cigányok és szegények Magyarországon, Romániában és Bulgáriában. Szociológiai Szemle. 4. 72-94. o.

László M.-Tomay K. (2002) A Westend árnyékában. - Szociológiai Szemle. 3. 66-90. o.

Lehrer, U. (2005) Image Building and Neoliberalism. Brock University. ESF Final Conference. Helsinki, Finland.

Lengyel I.-Rechnitzer J. (2000) A városok versenyképességérõl. - Horváth Gy.-Rechnitzer J. (szerk.) Magyarország területi szerkezete és folyamatai az ezredfordulón. MTA Regionális Kutatások Központja, Pécs. 130-153. o.

Lichtenberger, E.-Cséfalvay, Z.-Paal, M. (1994) Stadtverfall und Stadterneurung in Budapest. Verlag der Österreichischen Akademie der Wissenschaften, Wien.

Lukovich T.-Csontos J. (2002) A mi Budapestünk. Pallas Stúdió, Budapest.

Molotch, H. (2005) Cities and Terrorism. (Konferencia elöadás) ESF Final Conference Helsinki, Finland.

Muir, T. (2005) The Regeneration of Old Industrial Cities Case Study-Birmingham. University of Central England. ESF Final Conference. Helsinki, Finland.

Nagy, G. (2004) Measuring the activity of the information society. Creating regional, county and town level information indexes (in the case of Hungary). - Retkiewicz, W. (ed.) Formation of Information Society in the Regions of Uniting Europe. University of Lodz Department of Space Economy and Spatial Planning, Lodz. 124-149. o.

Nemes Nagy, J. (2000) The new regional structure in Hungary. - Petrakos, G.-Maier, G.-Gorzelak, G. (eds.) Integration and Transition in Europe: The Economic Geography of Interaction. Routledge, London.

Nemes Nagy, J. (2001) Local development, institutions and conflicts in the post-socialist Hungary. M. Keune. J-Nemes Nagy J. (eds.) ILO, Budapest.

Rechnitzer J. (1993) Szétszakadás vagy felzárkózás - a térszerkezetet alakító innovációk. MTA RKK, Győr.

Sassen S. (2000) Elveszített kontroll? Szuvenerítás a globalizáció korában. Helikon Kiadó, Budapest.

Smith, D.A. (2004) Global cities in East Asia: empirical and conceptual analysis. - International Social Science Journal. 181. 399-412. o.

Stenning, A. (2004) Urban change and the localitites. - Bradshaw, M.-Stenning, A. (eds.) East Central Europe and the Former Soviet Union, The Post-Socialist States. Harlow, Pearson. 87-109. o.

Szelényi, I. (1987) Housing Inequalities and Occupational Segregation in State Socialist Cities. International Journal of Urban and Regional Research. 11. 1-9. o.

Szemzö H.-Tosics I. (2004) Large Housing Estates in Hungary, Policies and practices. Restate. Utrecht.

Szirmai V.-Baráth G.-Molnár B.-Szépvölgyi Á. (2003) Globalizáció és térségi fejlődés. - Tér és Társadalom. 3. MTA Regionális Kutatások Központja, Pécs. 29-59. o.

Szirmai V.-Baráth G. (2003) Globalizzazione e urbanistica, la cultura cittadina a Budapest. Il ruolo della pianificazione delle citta' e dell'architettura. - Claudio Stroppa: La cultura urbana tra passato e futuro. Collana di sociologia, Franco Angeli. 222-239. o.

Szirmai V. (2004) Globalizáció és a nagyvárosi tér társadalmi szerkezete. -Szociológiai Szemle. 4. 3-25. o.

Szirmai, V. (1998) "Socialist”Cities (New Towns) in the Postsocialist Era. - Enyedi, Gy. (ed.) Social Change and Urban Restructuring in Central Europe. Akadémiai Kiadó, Budapest. 169-189. 0.

Szirmai, V. (2005) Introduction to the State of the Hungarian Urban Research. (Conference paper) ESF Final Conference. Helsinki, Finland. 26-28 May.

Szirmai, V.-A. Gergely, A.-Baráth, G.-Molnár, B.-Szépvölgyi, Á. (2003) The City and its Environment: Competition and/or Co-operation? (A Hungarian Case Study). - Discussion Papers. 41. Centre for Regional Studies, Pécs.

Timár J.-Velkey G. (szerk.) (2003) Várossiker alföldi nézöpontból. (Urban Success from Great Plain View.) MTA RKK Alföldi Tudományos Intézete, MTA Társadalomkutató Központ, BékéscsabaBudapest. 2003.

Vidor F. (2005) Képek és képtelenségek a városok világúban. Terc Kiadó, Budapest.

Weclawowicz, G. (1998) Social Polarisation in Postsocialist Cities. - Enyedi, Gy. (ed.) Social Change and Urban Restructuring in Central Europe. Akadémiai Kiadó, Budapest. 35-55. o.

Wing-shing, T. (2005) Cities in China. (Konferencia előadás) ESF Final Conference. Helsinki, Finland. 


\title{
THE PRINCIPLES OF DEVELOPMENT OF URBAN STUDIES: THE FUTURE OF THE EUROPEAN URBAN SCIENCES
}

\author{
VIKTÓRIA SZIRMAI
}

The main thesis of the article is the increase of the social, political and economic importance of urban areas in Europe. Several factors prove this importance including scientific cooperation, international comparative studies, the creation of new urban research centres, the establishment of new urban master programs at universities and international conferences. A significant international conference was organised by the European Sciences Foundation in Helsinki between 26 and 28 May 2005, where the participants discussed the future of European urban sciences and new urban research directions.

This article presents the main findings of this conference and the latest critical methodological aspects of the development of urban studies and compares the Hungarian and European research topics generated by urban social problems. The article concludes that there is no significant difference between the Hungarian and European research topics, but at the beginning of the 1990s Hungarian researches dealt mainly with the management of the urban economic crisis due to the political and economic transition processes, with economic modernisation and with integration into the world economic system. The social consequences and social conflicts of the transition period in urban areas received less attention. Recently we can see a shift in this approach towards social urban issues due to the European integration process and the increase of urban social problems during the second half of the 1990s. 